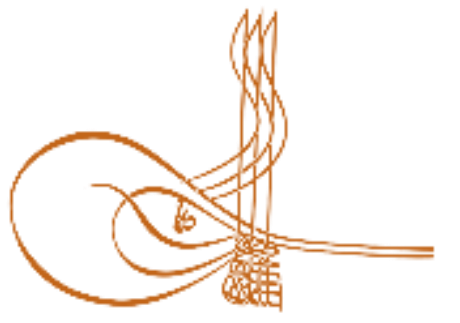

www.turkishstudies.net/turkishstudies
Turkish Studies

eISSN: $1308-2140$

Research Article / Araştırma Makalesi

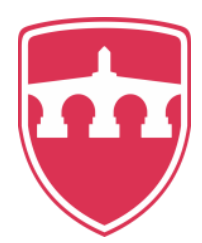

INTERNATIONAL

BALKAN

UNIVERSITY

Sponsored by IBU

\title{
Türk Televizyon Dizilerinin Azerbaycan Toplumu Üzerindeki Sosyo-Kültürel Etkilerini Anlamaya Yönelik Bir Değerlendirme
}

\author{
An Evaluation Towards Understanding the Socio-Cultural Impacts of Turkish Television Series on \\ the Azerbaijani Society*
}

\author{
Aykut Sığın $^{* *}$ - Raheb Mohammedi Ghanbarlou***
}

\begin{abstract}
The prevalence of media tools, especially of visual media products, via technological advances, cultural transmission between societies through these products and their effects on the socio-cultural fabric of the target society have become important phenomena of today's world. Turkey, being no exception in this regard, has become one of the front runners of producing television series and of transferring these popular media products to different countries, showing improvement both in quantity and quality recently. Moving on from this point, the media products in question were not only broadcasted in Turkish television channels, but were also exported to many different countries. The fact that media products occupy the agenda of societies and affect ways of social life necessitates the analysis of this issue from a sociological point of view. Therefore, the aim of this study is to investigate the socio-cultural effects of the Turkish television series on the "fellow" Azerbaijani society, whose kinship to Turkey originates both from an ethnic point and from similar ways of social living. The research was conducted in 2019 in Baku, the capital of the Republic of Azerbaijan. In carrying out the study, the series exported from Turkey to Azerbaijan were taken as media products and semi-structured interviews were held with 20 interviewees, whom were reached using snowball sampling. The interviewees were aged between 25 and 45 and 8 of them were women, whereas 12 of them were men. The obtained data were interpreted by taking the existing literature into consideration. While analyzing the issue at hand, it was aimed to explain the aspects in which the Azerbaijani society is impacted by the Turkish series and the ways they affect it. In this direction, chiefly the following questions were tried to be answered: What are the attitudes
\end{abstract}

\footnotetext{
* Bu çalışma 4. Uluslararası AVRASYA Multidisipliner Çalışmalar Kongresi’nde “An Evaluation towards Understanding the Socio-Cultural Impacts of Turkish Television Series on the Azerbaijani Society" başlığıyla literatür değerlendirmesinin yöntem olarak belirlendiği hâliyle sunulmuş, yapılan katkılarla yarı yapılandırılmış mülakat tekniğinin çalışmanın amacına daha uygun olacağı anlaşılmıştır. Yazarlar, değerli katkılarından dolayı kongre katılımcılarına teşekkürlerini sunar.

** Dr. Öğr. Üyesi, Aksaray Üniversitesi, Sağlık Hizmetleri Meslek Yüksekokulu, Çocuk Bakımı ve Gençlik Hizmetleri Asst. Prof. Dr., Aksaray University, Health Services Vocational School

ORCID 0000-0002-1197-552X

aykutsgn@gmail.com

*** Dr. Öğr. Üyesi, Avrasya Üniversitesi, Sağlık Bilimleri Fakültesi, Sosyal Hizmet Bölümü

Asst. Prof. Dr., University of Eurasia, Faculty of Health Sciences

ORCID 0000-0003-3606-3524

rahib.mahammadi@gmail.com

Cite as/ Atıf: Sığın, A., Ghanbarlou, R. M. (2020). Türk televizyon dizilerinin Azerbaycan toplumu üzerindeki sosyokültürel etkilerini anlamaya yönelik bir değerlendirme, Turkish Studies, 15(1), 583-592. https://dx.doi.org/10.29228/TurkishStudies.37366

Received/Geliş: 19 September/Eylül 2019

Accepted/Kabul: 25 February/Şubat 2020

Copyright $(\mathrm{C}$ MDE, Turkey

Checked by plagiarism software

Published/Yayın: 29 February/Şubat 2020

CC BY-NC 4.0
} 
of the Azerbaijani society towards the socio-cultural aspect of Turkish media products? What kinds of effects do the Turkish media products have on the Azerbaijani social life? At the end of the study, the Azerbaijani society's evaluations of Turkey and the former's changed perceptions, attitudes and behavior influenced by television serials came up as important research fields.

Structured Abstract: The prevalence of media tools, especially of visual media products, via technological advances, cultural transmission between societies through these products and their effects on the socio-cultural fabric of a target society have become important phenomena of today's world. Turkey, being no exception in this regard, has become one of the front runners of producing television series and of transferring these popular media products to different countries, showing improvement both in quantity and quality recently. Moving on from this point, the media products in question were not only broadcasted in Turkish television channels, but were also exported to many different countries. The fact that media products occupy the agenda of societies and affect ways of social life created a need to analyze this issue from a sociological point of view.

Therefore, the aim of this study is to investigate the socio-cultural effects of the Turkish television series on the "fellow" Azerbaijani society, whose kinship to Turkey originates both from an ethnic point and from similar ways of social living. The research was conducted in 2019 in Baku, the capital of the Republic of Azerbaijan. In carrying out the study, the series exported from Turkey to Azerbaijan were taken as media products and semi-structured interviews were held with 20 interviewees, whom were reached using snowball sampling. The interviewees were aged between 25 and 45 and 8 of them were women, whereas 12 of them were men. The interview questions asked the interviewees are as follows: 1-How often do you watch Turkish series? 2-Do you think Turkish series have some kind of effect on your life? Please explain. 3-Do you think Turkish series have any effects on the Azerbaijani society? Please explain. The obtained data were interpreted by taking the existing literature into consideration.

While analyzing the issue at hand, it was aimed to explain the aspects in which the Azerbaijani society is impacted by the Turkish series and the ways they affect it. In this direction, chiefly the following questions were tried to be answered: What are the attitudes of the Azerbaijani society towards the socio-cultural aspect of Turkish media products? What kinds of effects do the Turkish media products have on the Azerbaijani social life? At the end of the study, the Azerbaijani society's evaluations of Turkey and the former's changed perceptions, attitudes and behavior influenced by television serials came up as important research fields.

The findings of the study were categorized under three main themes and these were the cultural impact of the Turkish television series on the Azerbaijani society, the impact of the Turkish television series on the social living of the Azerbaijani society and the impact of the Turkish television series on the Azerbaijani youth and women. All three subheadings pointed out to a dichotomy of positive and negative evaluations. Under the first subheading, it was found out that the interviewees positively regarded the Turkish series as fortifying the national ties between the Turkish and Azerbaijani societies and as representing women as both powerful and free, whereas they negatively regarded the Turkish series as threatening the Azerbaijani language due to not being dubbed and instead being broadcasted in Turkish as spoken in Turkey. Under the second subheading, the interviewees evaluated the series in question as having a positive effect by means of portraying and bringing to the foreground a "European lifestyle" in a libertarian fashion. However, it was considered to be a negative impact that these series promote a capitalist lifestyle by way of leading the audience to consumerism and encouraging individualism. In addition to that, it was repeatedly expressed by the interviewees that these series legitimize, encourage and even justify adultery. Other than that, the interviewees often evaluated the impact of Turkish television series on two groups: the young and women. Therefore, a subheading dealing specifically with these two groups was deemed mandatory. Under the said subheading, on the one hand, the series were positively regarded as fortifying the notion of nationalism among the youth and portraying women as selfsufficient individuals and yet on the other hand, they were negatively evaluated as being a pointless leisure activity for the youth and portraying women as flirtatious and easy in addition to legitimizing violence against women. Finally, the series could often be said to have a quick and transient effect on such areas as consumption habits, priorities, political views, domestic interactions and music choice on the Azerbaijani society as products of popular culture.

Keywords: Media Products, Media Effects, Turkish Series, The Azerbaijani Society, Popular Culture 
Öz: Kitle iletişim araçlarının, özellikle de görsel medya ürünlerinin, teknolojik gelişmeler sayesinde hızlıca yayılması, bu ürünler aracılığıyla toplumlar arası kültür aktarımı ve yine bu ürünlerin hedef toplumun sosyokültürel dokusundaki etkileri günümüzün önemli olgularından olmuştur. Türkiye de bu konudan müstesna olmayarak son zamanlarda genelde popüler kültür ürünlerinin, özelde ise dizi filmlerinin üretiminde ve üretilen bu medya çıktılarının farklı ülkelere aktarımı konusunda hem niceliksel hem de niteliksel artış gösteren başat aktörlerden biri hâline gelmiştir. Bu noktadan hareketle, söz konusu medya ürünleri sadece Türkiye'deki televizyon kanallarında gösterilmekle sınırlı kalmamış, birçok farklı ülkeye de ihraç edilmiştir. Medya çıktılarının toplumların gündemini meşgul etmesi ve toplumsal yaşam biçimlerini etkilemesi de bu konunun sosyolojik açıdan incelenmesi gereksinimini ortaya çıkarmıştır. Dolayısıyla da bu çalışmada, son zamanlarda Türk dizilerinin gerek etnik yapıların gerekse toplumsal yaşamların benzerlik arz etmesi itibariyle "kardeş" ülke Azerbaycan toplumu üzerinde meydana getirdiği sosyo-kültürel etkilerin sosyolojik bir bakış açısıyla incelemeye tabi tutulması amaç edinilmiştir. Araştırma, 2019 yılında Azerbaycan Cumhuriyeti'nin başkenti Bakü'den seçilen katılımcılar üzerinde gerçekleştirilmiştir. Çalışma yürütülürken Türkiye'den Azerbaycan'a ihraç edilen medya çıktıları olarak diziler hakkındaki katılımcı görüşleri yarı yapılandırılmış görüşme yöntemiyle toplanmış, literatürde bulunan veriler de dikkate alınacak şekilde yorumlamalarda bulunulmuştur. 25-40 yaş aralığındaki 8'i kadın, 12'si erkek 20 katılımcıdan oluşan örneklem grubuna kartopu örnekleme yöntemiyle ulaşılmıştır. Konu ele alınırken Azerbaycan toplumunun Türk medya ürünlerinden etkilendiği boyutların neler olduğu ve söz konusu boyutların etki ediş biçimleri açıklanmaya çalışılmıştır. Bu doğrultuda, temel olarak aşağıdaki sorulara cevap aranmıştır: Azerbaycan toplumunun Türk medya ürünlerinin sosyokültürel boyutuna yönelik tutumları nelerdir? Türk medya ürünlerinin Azerbaycan'daki toplumsal yaşam üzerinde ne tür etkileri bulunmaktadır? Çalışmanın sonucunda, medya çıktıları olarak diziler üzerinden Azerbaycan halkının Türkiye'ye yönelik değerlendirmeleriyle birlikte, değişen algı, tutum ve davranışları önemli inceleme alanları olarak kendilerini göstermişlerdir.

Anahtar Kelimeler: Medya Ürünleri, Medya Etkileri, Türk Dizileri, Azerbaycan Toplumu, Popüler Kültür

\section{Giriş}

Kanadalı medya kuramcısı McLuhan 1962 yılında "Küresel Köy" kavramını kullanarak küresel kültürün genişleyerek dünyanın her yerinde etkisini gösterdiğini ifade etmiştir. Bu gerçeği mümkün k1lan, teknoloji alanındaki gelişmeler ve bunun sonucunda kültürün anlık olarak paylaşılabilmesi durumu olmuştur. Aynı kuramcı 1964 yılında "araç mesajdır" diyerek ise ilgiyi, küresel kültürün yayılışından, bu yayılmayı sağlayan kitle iletişim araçlarına yönlendirmiştir.

McLuhan'ın kavramsallaştırmaları günümüzde de geçerliliğini korumanın ötesinde, daha önemli bir boyuta ulaşmıştır. Öyle ki, post-modern dünyada kitle iletişim araçları hem daha çok yaygınlaşıp çeşitlenerek hem de toplumsal yaşam üzerindeki etkilerini gitgide arttırarak McLuhan'ın Küresel Köy ve aracın başlı başına bir mesaj olduğu tezlerini daha da güçlendirmiştir. Özellikle 2000'li yılların başlarında kullanıcılara kendi içeriklerini üretebilme imkânı sağlayan yeni medyanın doğuşuyla televizyon ve radyo gibi geleneksel kitle iletişim araçları etkilerini kaybediyor gibi görünmüş olsa da bunun tam anlamıyla geçerli bir durum olduğunu söylemek güçtür. Televizyon özelinde konuşulacak olursa, 2010 yılında dünya çapında 1.45 milyar evde televizyon bulunmaktayken bu sayı 2017 yılında 1.63 milyara yükselmiştir ve aynı sayının 2023 yılı itibariyle 1.74 milyara ulaşması öngörülmektedir (Watson, 2018).

Televizyon programlarının bir toplumun sosyo-kültürel dinamikleriyle refleksif bir ilişki içerisinde olduğu dikkate alındığında bu kitle iletişim aracının sosyal gerçeklikte ne kadar önemli olduğu daha iyi anlaşılmaktadır. Bir kültür yayma aracı olarak düşünüldüğünde de televizyonun büyük etkileri bulunmaktadır. Özellikle ulus devlet bakış açısından, sınırları çizilmiş toprak parçalarını yayınlar aracılı̆̆ıyla rahatlıkla aştığı görülen televizyon, bir toplumun değerlerini, geleneklerini, göreneklerini, normlarını ve yaşam tarzlarını başka bir topluma rahatlıkla taşıyabilmektedir. 
Burada değinilmesi gereken bir nokta da Joseph Nye tarafından 1990 yılında "Bound to Lead: The Changing Nature of American Power" başl1klı kitabında öne sürülen "yumuşak güç" ("soft power") kavramıdır. Yumuşak güç, uluslararası ilişkilerde sert gücün ("hard power") tersine ekonomik ve askeri kuvvet kullanımından ziyade ağlar kurarak, ikna edici anlatımlar yaparak, uluslararası kural ve yasalar oluşturarak ve bir ülkeyi dünyaya çekici kılan unsurları ön plana çıkararak yaratılmaya çalışılan etki olarak tanımlanabilir. (www.softpower30.com/what-is-softpower, 2018) Bir ülkenin yumuşak gücünün başlıca kaynakları o ülkenin kültürü, siyasi değerleri ve dış politikaları olarak sıralanabilir. Mevcut çalışma bağlamında yumuşak gücün kültürel boyutu önem arz etmektedir. Öyle ki, bir ülkenin kültürü başkalarına çekici geldiği durumlarda yumuşak güç olarak değerlendirilebilir (Nye, 1990b: 167) ve medya ürünleri, özellikle de televizyon programları, bu tarz bir algının oluşturulması için uygun koşulları sağlayabilmektedir.

Televizyon dizileri bir toplumun genel yaşayış tarzına ilişkin fikir verdiği için bu alanın en etkili ürünlerinden biri olarak kabul edilebilir. Özel olarak Türk dizilerine bakıldığında, bu dizilerin 140'1 aşkın ülkeye ihraç edildiği görülmektedir. Küresel ihracat oranlarına bakıldığında bu sayının Türkiye'yi Amerika Birleşik Devletleri'nin ardından ikinci sıraya koyduğu anlaşılmaktadır. Amerika Birleşik Devletleri'nden Rusya'ya, Balkanlar'dan Orta Doğu'ya, Uzak Doğu'dan Latin Amerika'ya geniş çaptaki coğrafyalarda milyonlarca kişi tarafından izlenen Türk dizileri günümüzde aşağı yukarı 350 milyon dolarlık bir sektöre karşılık gelmektedir. (https://www.haberturk.com/turk-dizilerindenekonomiye-milyon-dolarlik-ihracat-katkisi-1781496-ekonomi, 2018)

\section{Araştırmanın Amacı}

Azerbaycan ve Türkiye Cumhuriyetleri etnik köken bakımından Türk kavminin Oğuz boyuna mensuptur ve bağımsızlık sonrası Azerbaycan'da sıklıkla kullanılan "tek millet, iki devlet" söylemi birtakım ortaklıklara işaret etmektedir. Öte yandan, her iki ülke de uzun yıllar boyunca farklı medeniyetlerle etkileşimlerden geçtiği için bu toplumların yaşayışlarında, toplumsal yapılarında, değer ve inançları ekseninde kimi farklılıklara rastlamak mümkündür. Bu çalışmanın amacı, yoğunlukla 2000'li yıllardan itibaren Türkiye'den dünyanın çeşitli ülkelerine ihraç edilmeye başlanan Türk dizilerinin gerek etnik yapıların gerekse toplumsal yaşamların benzerlik arz etmesi itibariyle "kardeş" ülke Azerbaycan toplumu üzerindeki sosyo-kültürel etkilerini anlamaya çalışmaktır.

\section{Araştırmanın Yöntemi}

Mevcut araştırma 2019 y1lında Azerbaycan Cumhuriyeti'nin başkenti Bakü'den seçilen katılımcılar üzerinde gerçekleştirilmiştir. Çalışma yürütülürken nitel veri toplama yöntemi kullanılmıştır. Bu bağlamda, çalışmanın amacına ve konusuna uygun olarak 20 katılımcıyla görüşme yöntemi kullanılmıştır. Araştırma yürütülürken Türkiye'den Azerbaycan'a ihraç edilen medya çıktıları olarak dizilere ilişkin katılımcı görüşleri yarı yapılandırılmış görüşme yöntemiyle toplanmış, literatürde bulunan veriler de dikkate alınacak şekilde yorumlamalarda bulunulmuştur. 25-40 yaş aralığındaki katılımcıların oluşturduğu 20 kişilik örneklem grubuna kartopu örnekleme yöntemiyle ulaşılmıştır. Katılımcıların cinsiyet dağılımı Tablo 1.1.'de, eğitim düzeylerinin dağılımı ise Tablo 1.2.'de sayı ve yüzde olarak verilmiştir.

Tablo 1.1. Katılımcıların Cinsiyet Dă̆glımı

\begin{tabular}{|l|l|l|}
\hline Cinsiyet & Sayı & Yüzde \\
\hline Kadın & 8 & $\% 40$ \\
\hline Erkek & 12 & $\% 60$ \\
\hline Toplam & 20 & $\% 100$ \\
\hline
\end{tabular}


Tablo 1.2. Katılımcıların Eğitim Düzeyi Dağılımı

\begin{tabular}{|l|l|l|}
\hline $\begin{array}{l}\text { Ĕ̈itim } \\
\text { Düzeyi }\end{array}$ & Sayı & Yüzde \\
\hline Ön lisans & 6 & $\% 30$ \\
\hline Lisans & 12 & $\% 60$ \\
\hline Lisansüstü & 2 & $\% 10$ \\
\hline Toplam & 20 & $\% 100$ \\
\hline
\end{tabular}

Çalışma kapsamında katılımcılara yöneltilen sorular aşağıdaki gibidir:

1-Türk televizyon dizilerini ne sıklıkla izliyorsunuz?

2-Türk televizyon dizilerinin sizin yaşamınız üzerinde herhangi bir etkisi olduğunu düşünüyor musunuz? Açıklayınız.

3-Türk televizyon dizilerinin Azerbaycan toplumu üzerinde herhangi bir etkisi olduğunu düşünüyor musunuz? Açıklayınız.

\section{Azerbaycan ve Televizyon Yayınları}

Azerbaycan, Sovyet Sosyalist Cumhuriyetler Birliği'nin bir parçasıyken ve "Azerbaycan Sovyet Sosyalist Cumhuriyeti” adıyla bilinirken, Radyo ve Televizyon Kurumu 1926'da Bakü'de kurulmuştur. Radyo, çoğunlukla Azerbaycan Türkçesinde yayın yapmış ancak Rusça, Arapça, Farsça, Türkçe, İngilizce, Talişçe, Ermenice, Kürtçe ve Lezgice programlara da yer vermiştir. 14 Şubat 1956 tarihine gelindiğindeyse Azerbaycan toplumunun televizyonla tanıştığı görülmektedir. 1956'da Azerbaycan'ın başkenti Bakü'de bir televizyon merkezi kurulmuş ve o zamanlar ilk önce haftada iki kez, sonrasında ise üç kez ikişer saatlik programlar sunulmuştur (shorturl.at/fjoyA, 2019).

$\mathrm{Bu}$ gelişmeleri takiben, televizyon faaliyetleri Moskova merkezli olarak kurulmuş ve daha sonra kapsamı genişletilerek diğer cumhuriyetlere de yayılmaya başlamıştır. Sovyet Sosyalist Cumhuriyetler Birliği döneminde televizyon yayınlarıyla ilgili kararlar iktidarda olan Komünist Parti'nin merkez komitesinde alınmaktaydı. Haziran 1957'de Azerbaycan Özerk Cumhuriyeti'nin Nahcivan ve Hankendi şehirlerinde "Azerbaycan Devlet Televizyon ve Radyo Programları Komitesi" isminde bir oluşum kurulmuştur. AZTV1 1956'da Azerbaycan'da faaliyete geçen ilk devlet televizyonudur ve bu televizyon kanalında Azerbaycan Türkçesi, Rusça ve İngilizce programlar yayınlanmıştır. Söz konusu programların içerikleri iktidar tarafından ciddi şekilde denetlenmekte ve yayınlanan programlarda eleştirel ve yönetim karşııtı içeriklere izin verilmemekteydi. Bunun yanında, AZTV1'de canlı yayınlar yalnızca resmî devlet törenleri ve spor programlarıyla sınırlı tutulmuştur (Uluslararası İşbirliğgi Genel Müdürlügü, 2019).

Sovyetler Birliği'nin yıkılmasından sonra Azerbaycan medyası da diğer birçok alanda olduğu gibi birtakım değişimler yaşamıştır (Enserov ve Yurdigül, 2016: 352). Bu değişimler, kapitalist dünya anlayışının karşısında duran komünist sistemin etkisini aşamalı olarak yitirmesi çerçevesinde değerlendirilebilir. Öyle ki, günümüze gelindiğinde Azerbaycan televizyonlarının kapitalizmle hızlı bir eklemlenme süreci yaşadığı anlaşılmaktadır: 4 tanesi devlet kanalı, 43 tanesi özel kanal olmak üzere toplamda 47 televizyon kanalı hâlihazırda Azerbaycan'da yayın hayatına devam etmektedir (https://medialandscapes.org/country/azerbaijan/media/television, 04.09.2019).

Özel kanallar büyük miktarlarda devlet yardımı da almış, böylelikle özellikle 2000'li yılların başlarında eğlence programları Azerbaycan televizyon kanallarında çoğalmaya başlamıştır. Bu eğlence programlarının çoğunlukla Türkiye'deki televizyon kanallarında görülen eğlence programlarının benzerleri olduğu bilinmektedir. Tecavüz, şiddet ve aldatma gibi konuların bu tarz televizyon programlarında sıklıkla tartışılan temalar olduğunu belirtmek de bu konuların mevcut çalışmanın bulgularıyla örtüşmesi bakımından önem arz etmektedir. Bugün Azerbaycan televizyonlarında kişiler arası drama barındıran yayınların yaygın olduğu görülmekte, bu yaygın 
olma durumunun, sanat camiası başta olmak üzere, çeşitli çevrelerce eleştirildiği bilinmektedir. (https://eurasianet.org/with-state-help-azerbaijani-tv-aims-at-the-bottom, 2019)

\section{Etkileri}

2. Türk Televizyon Dizilerinin Azerbaycan Toplumu Üzerindeki Sosyo-Kültürel

Çalışma yürütülürken elde edilen veriler ışığında Türk dizilerinin Azerbaycan toplumu üzerindeki etkilerini üç temel tema altında toplayacak şekilde özetlemenin mümkün olduğu anlaşılmıştır. Söz konusu temalar şu şekilde sıralanabilir: Türk dizilerinin Azerbaycan toplumu üzerindeki kültürel etkileri, Türk dizilerinin Azerbaycan'daki toplumsal yaşam üzerine etkileri, Türk dizilerinin Azerbaycan'daki gençler ve kadınlar üzerindeki etkileri.

\subsection{Türk Dizilerinin Kültürel Etkileri}

Genel olarak dizilerde sunulan programlar insan yaşamında olan ve olma ihtimali taşıyan her şeyi kapsamaktadır. Söz konusu unsurlar kültürel bağlam içinde yer almakta, bu çerçeve dâhilinde gerçekleşmektedir. Mevcut çalışmada katılımcıların televizyon dizilerinin kültürel boyutuna yönelik tutumları olumlu ve olumsuz etkiler olmak üzere iki kategoride değerlendirilmiştir.

İlk olarak, kültür ile vazgeçilmez bir bağa sahip olan önemli unsurlardan birisinin iletişim olduğu anlaşılmalıdır. Dilin kültür aktarımındaki birincil dereceden önemi genelgeçer kabul görmüş bir konudur. Dil, kitle iletişim araçlarında kullanılış biçimleri itibariyle bu araçların etki alanı içinde yer almaktadır. Öyle ki, toplumsal yaşamımızda kullanılan sembollerin en gelişkin bölümüne karşılık gelen dil, kitle iletişimde en temel unsur olarak karşımıza çıkmaktadır (Oskay, 2002: 342). Bunun ötesinde, dil ve düşünce arasında sıkı ve birbirini tamamlayan bir bağ vardır. Dil, düşüncelerin intikal edilmesinde kullanılan kalıplardan meydana gelmektedir. Dil, bu yönüyle en yaygın kitle iletişim araçlarından olan televizyonda da yoğun bir biçimde kullanılmaktadır. Azerbaycan toplumu da Türkiye gibi Türkçe'nin Oğuz grubuna ait olduğuna göre Türk dizileri dünyanın diğer bölgelerine göre dublaj müdahalesine ihtiyaç duymaksızın kaynak dil ile izlenebilmektedir. Bu da dizilerin daha çok popüler olması, verilen mesajların daha kolay anlaşılması, reytinglerin görece yüksek olması, dizilerdeki birçok içerik gibi dilin de benimsenmesi gibi sonuçları beraberinde getirmektedir. Ancak bu durumun olumsuz bir yansıması olarak, Azerbaycan Cumhurbaşkanı üst düzey yardımcısı/danışmanı Arşad Aliyev'in Türk dizilerinin Azerbaycan'da Azeri dilini tahrip ettiğine yönelik söylemleri gündeme gelmiştir (http://www.milliyet.com.tr/cadde/ali-eyuboglu/turkdizilerine-konan-ilk-yasak-1535022, 2012). Buna bağlı olarak, 2017'de Türk dizilerine yayın yasağ1 getirilmiş, Aliyev bunun nedeni olarak bu dizilerin Azeri diline zarar verdiğini ve onu yok etme tehlikesiyle baş başa bıraktığını göstermiştir. Aliyev Türkiye'nin kardeş ve dost ülke olduğunu söylemiş ancak bunun, Azerbaycan Türkçesini yok etmek için bir gerekçe olamayacağını ifadelerine eklemiştir. Ona göre, nasıl ki Kazak ve Özbek dilleri yaşıyorsa Azeri dili de ayakta kalmalıdır. Bunun çözüm yolu olarak ise Türk dizilerinin Azerbaycan Türkçesinde dublajlanarak yayınlanması görülmüştür. Bu dilsel kaygı katılımcılar tarafından da paylaşılmıştır.

Çalışma kapsamında Türk dizilerinin Azerbaycan toplumu üzerindeki kültürel etkilerinden bir diğeri ise milliyetçilik olgusu etrafında şekillenmiştir. Bu durum, katılımcılar tarafından olumlu bir bağlam içerisinde ele alınmıştır. Öyle ki, bir katılımcı (erkek, bekâr) tarihsel içeriğe sahip Diriliş, Payitaht, Söz gibi dizilerin vatanseverlik değerlerini aşılaması itibariyle olumlu etkilere sahip olduğunu belirtmiştir:

Türk dizilerinde son zamanlarda tarihsel içerikli dizilere sık rastliyoruz. Bu diziler bizim kardeş ülke Türkiye'nin tarihini daha derinden öğrenmemizi sağlıyor. Ayrıca bize de tarihimizle gurur duymamızı ve tarihimizin önemini hatırlatıyor. Bence Türkiye tarihsel içerikli dizileri de çok iyi yapıyor. Çünkü bu dizilerin Azerbaycan'da çok izlendiğini düşünüyorum.

Bir başka katılımcı (erkek, bekâr) da aynı doğrultuda Türk dizilerinin Türkiye ve Azerbaycan halklarını birbirine daha da yakınlaştırdığı fikrini şu şekilde ortaya koymuştur: 
Bence Türk dizileri bir süredir konu bakımından tekrara düşmüştür. Hep aile konuları, ihanet, aldatma, cinayet... Fakat bu tarihsel içerikli diziler, özellikle Muhteşem Yüzyıl, benim tarihe ve tarihi geçmişe ilgimin artmasını sağladı. Aynı zamanda bu tarihi dizilerde millet olarak Türkiye ile ne kadar yakın olduğumuzu daha somut hissettim. Keşke daha ileride Azerbaycan ve Türkiye arasında ortak bir tarihi dizinin yapımına şahit olabilsek.

Diğer bir görüşmeci (kadın, evli) Azerbaycan televizyon kanallarında gösterilen Güney Amerika ve Rus dizilerine dikkat çekerek bu dizilerin Azerbaycan toplumunun kültürüyle uyuşmadığını ifade etmiş ve bu dizileri "kötü" olarak nitelendirmiştir. Aynı katılımcı bunun aksine Türk dizilerinin Azerbaycan toplumunun "özünü" yansıttığını belirtmiş ve söz konusu dizilerin milliyetçi duygular üzerindeki tetikleyici etkilerini gözler önüne seren söylemlerde bulunmuştur:

Biz daha önceleri Güney Amerika ve Rus dizilerini izliyorduk. Bunlar kültürümüzle hiç ilgisi olmayan dizilerdi. Fakat kendi ülkemizde başarılı dizi olmadığından ve başka seçeneğimiz olmadığından hep onları izlerdik. Şimdi ise Türk dizilerini izliyoruz ve çok mutluyuz, çünkü çok ortak noktamız vardır. Türk dizileri bizi yansıtıyor. Biz de Türk olduğumuzla, özümüzle gurur duyuyoruz. Biz ailecek akşamları bu dizilerle yaşıyoruz ve sabırsızlıkla dizilerin yayınlandığı saatleri bekliyoruz. Dizilerin yayınlandığı saatlere, çok önemli işimiz olmazsa, program koymuyoruz.

\subsection{Türk Dizilerinin Toplumsal Yaşam Üzerindeki Etkileri}

Televizyon dizilerinin etkisini ve önemini artıran önemli bir boyut da görselliğin bu ürünlerde oynadığı roldür. Görsellik, algılama ve anlama sürecini kolaylaştırmakta etkin bir faktördür. Görsel unsurlar hedef kitleye aktarılırken aynı zamanda mesaj iletimi de gerçekleştirilmektedir. Bu yüzden görsel unsurlarla sunulanların algılanması esnasında içeriğe kodlanmış mesajlar da izleyiciye ulaşacaktır. Bu türden bir iletim süreci kişilerin karşılaştıkları şeylere yönelik tutumlarında belirleyici rol oynayabilmektedir. Sahadan toplanan veriler açıkça göstermektedir ki Türk dizileri, katılımcıları yaşam tarzları, giyim kuşam stilleri ve yaşam algıları gibi hususlarda etkilemektedir. Dolayısıyla da yukarıda değinilen bağlamda dizilerdeki görsellik faktörü mesajın alınmasında ve davranışa yansımasında belli bir ölçüde etkili olmaktadır.

Türk dizilerinin Azerbaycan'daki toplumsal yaşam üzerindeki etkileri farklı noktalarda gözlemlenmiştir. Türk televizyon dizilerinin Azerbaycan toplumunun taşıdığı değerler, bu değerlerin değişmesi, bakış açılarındaki farklı1ıkların oluşturulması, herhangi bir olayın talep edilen biçimde ele alınması, beslenme alışkanlıklarının değişmesi, tüketim alışkanlıklarının farklılaşması gibi birçok konuda etkisinin olduğu görülmüştür. Bu bağlamda, katılımcılardan birinin (erkek, bekâr) ifadesi şu şekilde olmuştur:

Gözlemlediğim kadarıyla ve dünya sosyal medyasının toplum üzerindeki etkileri de göz önünde bulundurulursa sadece Türkiye TV programı ve dizileri değil, tüm dünyada olan TV programları ve dizilerinin yayınlanma amaçlarının altında kapitalist sistemin doğası gereği insanlarda bireyselliği öne çıkarmak ve bol para kazanmanın yollarını aramaya ve bol tüketim yapmaya yönlendirmek gibi kötü alışkanlıkların reklamını yapmak yatıyor. $\mathrm{Bu}$ durum, insanların kendi geleneklerinden uzaklaşmasına ve bencil bireylerle dolu bir toplumun oluşmasına neden olabiliyor.

Marx'ın yabancılaşma kavramıyla birlikte okunabilecek bu ifade, Frankfurt Okulu'nun kültür endüstrisi penceresinden bireyleri edilgen ve homojen kılan bir anlayışla da değerlendirilebilir. Katılımcının ifadesinde de görüldüğü üzere, dizilerde kurgulananlar izleyici tarafından model alınabilmektedir. Toplum ve diziler arasında meydana gelen bu tür bir etkileşimin bireylerin tutum ve davranışında hemen her an belirleyici olduğu yadsınamaz bir gerçektir.

Katılımcılardan toplanan verilerde önem arz eden hususlardan biri de Türk dizilerinin içerik ve senaryo bakımından eleştiriler almasına rağmen bu dizilere bağlılık oranının yüksek oluşudur. Özellikle hedef kitlenin bir diziden kopmaması ve hatta tekrarlarını bile büyük bir bağlılıkla takip etmesi dikkat çekicidir. Türk dizilerinin Azerbaycan'da toplumsal yaşama değişik biçimlerde etkisi; 
moda, beslenme, giyim kuşam, davranış biçimleri, tüketim alışkanlıkları gibi toplumsal hayatın her bir aşamasında gözlemlenmekte, bu diziler bireylerin anlayışlarını ve algılarını değiştirebilmektedir.

Çalışmada Türk dizilerinin Azerbaycan toplumu üzerindeki sosyo-kültürel etkileri araştırılırken dizilerin özellikle bazı tutumlar üzerinde değişimlere neden olduğu tespit edilmiştir. Bu çalışmanın verilerine istinaden, tutumlardaki değişimin toplumsal yaşamı birçok açıdan ilgilendirdiği anlaşılmıştır. Tüketim alışkanlıkları, yaşam tarzları, öncelikler, siyasi düşünceler, aile içi iletişim, müzik seçimleri gibi hususlar bu bağlamda örnek verilebilir.

Türk dizilerinde sıklıkla karşılaşılan şiddet içerikli yayınların etkileri bağlamında; toplumsal davranış, toplumsal olay ve süreçleri algılama ve sosyalleşme süreçlerine ilişkin birçok farklı sonuca ulaşıldığ 1 söylenebilir. Bu sonuçların en önemlileri arasında şiddet karşısında duyarsızlaşma, şiddeti uygulayan figürlerle özdeşleşme ve şiddeti meşru görülen bir olgu olarak algılama sıralanabilir. Şiddetin toplumsal algıda meşrulaştırılan bir zemine yerleşmesi, bireylerin benzer şekilde şiddet içeren davranışlarda bulunmalarına veya bu durumların, kendi başlarına da gelebileceği korkusuna sahip olmalarına sebebiyet verebilmektedir. Örneğin, konuyla ilgili bir katılımcının (kadın, bekâr) ifadesi şu şekildedir:

Hem olumlu hem de olumsuz etkilerinin olduğunu düşünüyorum. Biz Türk dizilerinden Avrupai yaşam tarzını takip edebiliyoruz. Moda konusunda aldığımız şeyler olmuştur. Fakat çocuk yaştaki insanlarda kötü tesir bırakabiliyor. Kadınların dayak yemesi, öldürülmesi, ihanet ve sık insan öldürmek sevmediğimiz şeylerdir.

Söz konusu görüşmecinin "Avrupai yaşam tarzı" ifadesi de diğer görüşmecilerin Türk dizileri hakkında büyük ölçüde katıldığı bir düşüncedir. Bir sonraki başlıkta farklı bir boyutuyla ele alınacak olan Batı değerlerinin bu dizilerde yoğun olarak temsil edildiği düşüncesi ve bu dizilerin tüketime yönelik, bireyci, özgürlükçü ve kapitalist bir yaşam tarzını öne çıkardığı anlayışı katılımc1ların ifadelerinden okunabilmektedir.

\subsection{Türk Dizilerinin Gençler ve Kadınlar Üzerindeki Etkileri}

Sosyalizasyon veya toplumsallaşma, toplumun değerlerini ve normlarını içselleştirerek ve toplumsal rollerimizi öğrenerek onun bir üyesi hâline geldiğimiz süreçtir ve bu süreç kişinin hayat1 boyunca devam eder. Süreci anlamak ve açıklamak üzere Freud, Piaget, Kohlberg ve Gilligan gibi birçok isim çalışmalar yürütmüştür. Bu sürecin aile, okul, kitle iletişim araçları ve akran grupları gibi birtakım yönlendiricileri bulunmaktadır. Dubow, Huesmann ve Greenwood (2007: 404) medyanın toplumsallaşma sürecindeki etkisini vurgularken bu etkinin ailenin ve okulun gösterdiği etkinin de önüne geçebileceğine değinmişlerdir. Medya, çocuklar için rol modeller ve çeşitli kişilik özelliklerindeki kurgu karakterler sunarak kimlik gelişimine katkıda bulunabilir.

Mevcut çalışmada bu argümanları destekleyecek şekilde, Azerbaycan'da Türk dizilerini izleyen çocukların etkilenmesine yönelik bir kaygının olduğu görülmektedir. Örneğin, bir görüşmeci (erkek, bekâr) dizilerin genç yaştakilere bir şey kazandırmadığını, dizi izlemek için kullanılan serbest zamanın sporla, ders çalışmakla veya kitap okumakla değerlendirilebileceğine değinmiştir:

Türk dizileri popülerdir ve son zamanlarda birçok ülkede izleniyor. Bunlar doğrudur. Fakat bence genç yaştaki insanlara çok bir şey kazandırmıyor. Çünkü onlar bu dizilerin konularını gerçek hayatlarında uygulayabilirler. Bence yaşl1lar veya yetişkinler tarafından hobi olarak izlenebilir. Fakat gençlere kötü örnekler oluşturabilir. Evlilik, aşk, aldatma, silahla sorunları çözme pek de iyi şeyler değil bence.

Türk dizilerini severek takip ettiğini söyleyen bir diğer görüşmeci (kadın, evli) yine de bu dizilerin gençler üzerinde olumsuz etkileri olabileceğinden bahsetmiştir. Bir diğer görüşmeci (kadın, bekâr) belirli olarak bir yaş grubuna değinmemiş olmakla birlikte, bir tanıdığının bir dizideki iletişim sürecini kendi hayatında deneyerek aynı sonucu elde etmeye çalıştı̆̆ını ifade etmiştir. 
Çalışmada göze çarpan bir başka bulgu da görüşmecilerin bu dizilerde kadının yansıtılma biçimine yönelik tutumlarıdaki farklılaşma olmuştur. Katılımcılar arasında genel olarak kabul gören görüş, Türk dizilerinde temsil edilen kadın imgesinin daha Batılı olduğudur. Ancak katılımcıların bu "Batılı kadın" imgesine yönelik bakış açısında biri olumsuz, diğeri olumlu olmak üzere bir tür ikiliğin görüldüğü söylenebilir. Örneğin, bir katılımcı (kadın, bekâr) Türk dizilerindeki kadın figürünün Azerbaycan'a kıyasla daha "özgür" olduğunu olumlu bir nitelik olarak ele almıştır (aynı katılımcı bazı kadınların dizilerden dolayı eşleriyle tartışmaya girdiklerini belirtmiş ancak bunu olumlu veya olumsuz bir durum olarak değerlendirmemiştir):

Türk dizilerinin sürekli izleyicisi sayılırım. Bu dizilerde ben kadınları özgür buluyorum. Örneğin, aşk, iş gibi konularda erkeklerle çok rahat konuşuyorlar. Karşllaştıkları engelleri bazen aşamasalar da mücadele cesaretleri vardır. Türk dizilerinde kadınlar sadece eş ve anne değil; iş hayatında da öne çıkarılıyorlar. Çoğu zaman bazı ailelerin sorumluluğunun kadınlar üzerinde olduğunu görüyoruz. Bu dizilerden bizimkiler de etkileniyor ve eşleriyle, babalarıyla, abileriyle tartışmaya girenler oluyor. Benim yakından tanıdığım bir arkadaşım bu dizilerden cesaret aldığını ve eşine karşı daha cesaretli olduğunu ve onunla tartıştığını anlatmıştı.

Bir diğer katılımcı (kadın, evli) bu dizilerdeki kadınları "başına buyruk" olarak ele almıştır. Benzer bir şekilde, bir görüşmeci (erkek, bekâr) Türk dizilerinin kadına yönelik şiddeti kınadığını belirtirken bir diğeri (kadın, evli), toplumsal cinsiyet eşitsizliğine vurgu yapacak şekilde söz konusu dizilerde kadına yönelik şiddetin sıklıkla yansıtıldığına değinmiştir:

Türk dizilerini ailecek izliyoruz. İlk yayınlandığında çok hevesliydik. Henüz konuları çok ayırt edemiyorduk. Ama bu dizilerin sayısı arttıkça kadınların çok dayak yediğini, öldürüldüğünü ve aşağılandığını gördük. Gerçi kadının güçlü gösterildiği durumlar da olmuştur. Bence bu şiddet içeren sahneler azalırsa, yerine sevgi ve uzlaşma konuları konulursa daha yapıcı olur ve aileler de bu dizileri çocuklarıyla rahat izleyebilirler. Çünkü bu diziler sanki bizdeki bir boşluğu doldurmuş gibi oldu. Devam etmesini isteriz. Fakat dediğim gibi, şiddet içeren sahneler azalırsa harika olur.

Bir görüşmeci (erkek, evli) Türk dizilerinin özendirici bir etkisinin bulunduğuna işaret edecek şekilde kadınların "dizilerde gördügü her şeye" merak duyduğunu ifade etmiştir. Bir diğer görüşmeci (erkek, bekâr) ise bu özendirici etkinin "kadınların sık ihanet ettiği" kaygısına zemin oluşturabileceğini belirtmiştir.

\section{Sonuç}

Birçok tartışmayı da beraberinde getiren ve toplumsal bir olgu hâline gelen televizyon dizilerinin, televizyonun özellikleri ve fonksiyonları ile birlikte sosyo-kültürel hayat üzerinde etkili olduğu herkes tarafindan kabul edilir bir konudur. Bu çerçevede, Türk dizilerinin Azerbaycan toplumu üzerindeki sosyo-kültürel etkilerini sosyolojik bir bakış açısıyla incelemek bu çalışmanın temel hedefini oluşturmuştur.

Sosyo-kültürel değişim ve iletişim arasında sıkı bir bağ bulunmaktadır. İletişim, değişimin gerçekleşmesi için ön koşulların oluşmasını sağlamaktadır. Bu bağlamda, Türkiye'deki dizilerin Azerbaycan'a ihraç edilmesi sosyolojik düzlemde önemli çağrışımları olan bir durum olarak değerlendirilmiştir.

Çalışmanın bulguları, Azerbaycan toplumunun Türk dizilerinden üç temel başlık altında toplanabilecek maddeler ölçüsünde etkilendiğini ortaya koymuştur. Bu başl1kların her biri olumlu ve olumsuz olmak üzere ikili şekilde değerlendirilmeye müsait veriler sunmuştur. Özetlemek gerekirse, Türk dizilerinin kültürel etkileri katılımcılar tarafindan olumlu yönden milli bağları kuvvetlendirici ve kadınların güçlü ve özgür olarak gösterilmesi şeklinde değerlendirilirken olumsuz yönden Azeri dilinin kaybolmasına sebebiyet verebileceği şeklinde ele alınmıştır. Türk dizilerinin toplumsal yaşam üzerindeki etkilerinden, bu dizilerin özgürlükçü bir tutumla "Avrupai yaşam tarzı"nı ön plana çıarması olumlu bir özellik olarak değerlendirilmiştir. Öte yandan, söz konusu dizilerin tüketime yöneltme, bireyciliği öne çıkarma gibi olgular üzerinden kapitalist bir yaşam tarzını teşvik etmesi katılımcılar tarafından olumsuz bir bakış açısıyla ele alınmış, yine bu dizilerin evlilik dışı ilişkileri 
meşrulaştırıcı bir zemin hazırladığı ifade edilmiştir. Bunun dışında, katılımcılar, gençler ve kadınlar özelinde ayrı bir başlık atmayı gerektirecek yoğunlukta bu iki grup için değerlendirmelerde bulunmuşlardır. $\mathrm{Bu}$ değerlendirmeler, Türk dizilerinin gençler ve kadınlar üzerindeki etkileri bağlamında gençlerdeki milli duyguları güçlendirme ve kadınları kendi kendilerine yetebilen bireyler olarak gösterme yönünden olumlu, gençlerin serbest zaman kullanımını değersizleştirme ve kadınları flörtöz olarak gösterme, kadına yönelik şiddeti meşrulaştırma gibi etkileri yönünden ise olumsuz etkiler olarak vurgulanmıştır. Popüler kültür bağlamında bakıldığındaysa, bu dizilerin Azerbaycan toplumunun tüketim alışkanlıkları, öncelikleri, siyasi düşünceleri, aile içi iletişimleri, beğendikleri müzik gibi alanlar üzerinde genelde hızlı ve geçici etkileri bulunduğu söylenebilir.

\section{Kaynakça}

Dubow, E. F., Huesmann, L. R. ve Greenwood, D. (2007). "Media and youth socialization: Underlying processes and moderators of effects." Handbook of Socialization. (Ed.) Joan E. Grusec ve Paul D. Hastings. New York: The Guilford Press.

Enserov, V. ve Yurdigül, Y. (2016). "Bağımsızlık dönemi Azerbaycan'ında radyo-televizyon alanında kamu ve devlet yayıncılı̆̆ının gelişimi”. Gümüşhane Üniversitesi İletişim Fakültesi Elektronik Dergisi, (4)1, 351-370.

http://www.milliyet.com.tr/cadde/ali-eyuboglu/turk-dizilerine-konan-ilk-yasak-1535022, Erişim Tarihi: 05.09.2019.

https://eurasianet.org/with-state-help-azerbaijani-tv-aims-at-the-bottom, Erişim Tarihi: 05.09.2019.

https://medialandscapes.org/country/azerbaijan/media/television, Erişim Tarihi: 04.09.2019.

https://www.haberturk.com/turk-dizilerinden-ekonomiye-milyon-dolarlik-ihracat-katkisi-1781496ekonomi, Erişim Tarihi: 20.07.2019.

McLuhan, M. (1962). The Gutenberg galaxy: The making of typograhpic man. Kanada: University of Toronto Press.

McLuhan, M. (1964). Understanding media: The extensions of man. Kanada: McGraw-Hill Education.

Nye, J. (1990a). Bound to lead: The changing nature of American power. New York: Basic Books.

Nye, J. (1990b). "Soft power." Foreign Policy, 80: 153-171.

shorturl.at/fjoyA, Erişim Tarihi: 16.09.2019.

softpower30.com/what-is-soft-power/, Erişim Tarihi: 18.07.2019.

Uluslararası İşbirliği Genel Müdürlüğ̈̈. (2019). Azerbaycan radyo televizyon kanallarıyla tanışıklık. Y11: 5, say1: 31.

Ü. Oskay. (2002). XIX. yüzyıldan günümüze kitle iletişiminin kültürel işlevleri: Kuramsal bir yaklaşım. İstanbul: Der Yayınları.

Watson, A. (2018). https://www.statista.com/statistics/268695/number-of-tv-householdsworldwide/, Erişim Tarihi: 14.07.2019. 